\title{
Measurement modelling of the perceived service quality of intercity bus terminal
}

\author{
Ashari Abdullah ${ }^{1, *}$, Ananto Yudono ${ }^{1}$, Sakti Adji Adisasmita ${ }^{2}$, and Arifuddin Akil ${ }^{1}$ \\ ${ }^{1}$ Hasanuddin University, Architecture Engineering Department, Gowa, Indonesia \\ ${ }^{2}$ Hasanuddin University, Civil Engineering Department, Gowa, Indonesia
}

\begin{abstract}
There is a tendency on decreasing effectiveness on the use of intercity bus as result of relocation, this is indicated from passengers' reluctance for transit in the terminal. This research aims to develop monitoring and service evaluation indicators in intercity bus terminal. This research is to test quality of service factors out of 19 indicators. This research is conducted in Makassar Metro Terminal. The data is collected through survey to 350 passengers. Results of Exploratory factor analysis (EFA) classify the indicators into 5 factors, namely: Terminal Performance, Connectivity, Ease of Transfer, Operator Performance, Reliability service. Confirmatory Factor Analysis (CFA) is used to confirm the formed factors. Results of the CFA show that the Connectivity and Ease of Transfer have quite high factor loading each of which is by 0,93 and 0,9 compared to 3 other factors so that two factors are the priority in improving terminal service performance.
\end{abstract}

\section{Introduction}

Bus Terminal is one of the components of intercity transportation system. In its development, it is necessary for policies on development of terminal, both new terminal and relocation terminal so that it can respond on the city growth. The relocation is conducted to solve any traffic congestion in former location as well as to increase terminal loading capacity [1]. However, the built terminal has not many activities, this is caused by passengers' reluctance for transit activity. This quiet terminal affects on the creation of illegal terminal having operation within the city either in arterial roads or private bus pool. It leads to some impacts, one of which is decreasing terminal performance related to the less of connectivity, so that the passengers do not use the terminal / halte [2]. There is a tendency on deregulation of transportation rules on intercity bus in some countries such as German, UK, USA, and Sweden not using terminal as transit facility. This bus transports or drops off passengers in predetermined curbside and can access city road [3].

This research aims to identify any factors affecting on quality of intercity bus terminal services. There is a great limitation on researches concerning intercity terminal so that in preparing these research indicators, there are literature studies having no cover on bus terminal [4], it is not only caused by very limited sources, but also by transfer facilities such

* Corresponding author: ashari.arsitek@gmail.com 
as interchange [5-11]. Although in the literature study, there are broad reviews on its scope not only on terminal, but in each prepared category indicators, it has included terminal/ transfer facility service quality indicator. From the literature studies, there is only studying on intercity terminal with Regression Model analysis method. From results of literature studies, there is none studying on quality of intercity bus terminal service [4].

\section{Desk study}

Out of some literature studies [5], studied on key factor an efficient transport interchange using 37 indicators divided into 8 categories. From the research results, the transfer information and condition are the main factor to improve transport interchange performance such as travel information, accessibility, coordination between transportation operators. [6] studied on intermodal transfer using 15 indicators divided into 7 categories. Coach Terminal using 22 indicators divided into 7 categories [4]. Interurban Interchange using 28 indicators divided into 8 categories [8]. LRT using 37 indicators of service quality divided into 8 categories [9]. Railway using 26 indicators using 7 factors [10]. Station using 16 indicators divided into 5 categories [12]. Service quality for railways passenger using 20 indicators divided into 5 categories [11]. Interchange using 40 indicators divided into 6 categories [7]. Intercity bus using 22 indicators divided into 4 categories [13]. Intercity of bus used 9 indicators [14].

Table 1. literature review in transportation

\begin{tabular}{|c|c|}
\hline $\begin{array}{c}\text { Author(s)/Year/Type Transfer Facility/Country, } \\
\text { Analysis Method }\end{array}$ & Category Of Service Quality \\
\hline $\begin{array}{l}\text { Hernandez \& Monzon (2016), Interchange, Finland- } \\
\text { Spain- UK, PCA }\end{array}$ & $\begin{array}{l}\text { Information, Transfer Condition, Safety \& Security, } \\
\text { Emegency Situation, Desain \& Image, Enviroment } \\
\text { Quality, Service \& Facilities, Comfort Of Waiting } \\
\text { Time }\end{array}$ \\
\hline $\begin{array}{l}\text { Silva and Bazrafshan (2013), Intermodal Transfer, } \\
\text { Portugal, EFA \& SEM }\end{array}$ & $\begin{array}{l}\text { Information, Convenience \& Easy Of Use, Security, } \\
\text { Facilities Quality, Global Comfort, Global Securyty, } \\
\text { Global Satifaction }\end{array}$ \\
\hline $\begin{array}{l}\text { Yatskiv et al. (2009), Coach Terminal, Latvia, } \\
\text { Regression Model }\end{array}$ & $\begin{array}{l}\text { Accesibility, Information, Time, Costumer Service, } \\
\text { Comfort, Relibility/saftey, Enviroment }\end{array}$ \\
\hline $\begin{array}{l}\text { Dell'Asin (2014), Interurban Interchange, Madrid, } \\
\text { MCA-CA }\end{array}$ & $\begin{array}{l}\text { Availibility, Accessibility, Information,Journey time, } \\
\text { Costumer Care, Comfort, Safety, Enviromental } \\
\text { Impact }\end{array}$ \\
\hline De Oña, Et Al. (2016), LRT, Spain, EFA-SEM & $\begin{array}{l}\text { Avalibility, Accesibiity, Information, Timelines, } \\
\text { Attention To Client, Comfort, Safety, Enviromental } \\
\text { Pollution }\end{array}$ \\
\hline $\begin{array}{l}\text { Eboli, et al. (2016), Railway, Italy, Multi Level } \\
\text { Fuzzy }\end{array}$ & $\begin{array}{l}\text { Saftey, Cleaniness, Comfort, Service, Information, } \\
\text { Personnel, Other }\end{array}$ \\
\hline Iseki and Taylor (2010), Station, US, CSI-IPA, OLR & $\begin{array}{l}\text { Aminities, Information, Connection \& Realibility, } \\
\text { Acces, Security \& Safety }\end{array}$ \\
\hline $\begin{array}{l}\text { Nathanail (2008), Railway, Hellenic, Multicriteria } \\
\text { Analysis }\end{array}$ & $\begin{array}{l}\text { Itenerary accuracy, System Safety, Cleaness, } \\
\text { Passenger Comfort, Servicing, Pasengger Information }\end{array}$ \\
\hline $\begin{array}{l}\text { Hine \& Scott (2000), Interchange, UK, qualitative } \\
\text { Method }\end{array}$ & $\begin{array}{l}\text { Waiting Environment, Information Provision, Service, } \\
\text { Costumer Care, Ticketing, Queuing }\end{array}$ \\
\hline Wen et.al (2005), Intercity bus, Taiwan, EFA-SEM & $\begin{array}{l}\text { On-board amenity,crews' attitude, station } \\
\text { performance, operational performance. }\end{array}$ \\
\hline $\begin{array}{l}\text { Bordagaray et al. (2013), Interurban buses/Spain, } \\
\text { Ordered Probit Model }\end{array}$ & $\begin{array}{l}\text { Waiting time, journey time, reliability, vehicle } \\
\text { occupancy, driver kind- ness, comfort, price of the } \\
\text { ticket, quality of the vehicle and available } \\
\text { information. }\end{array}$ \\
\hline
\end{tabular}


From results of literature study in this research, it is prepared 19 indicators to be tested to prepare the service quality factor using EFA and CFA. Benefits of this research will provide description on evaluation on service quality of intercity bus terminal. This research is conducted in Makassar Metro Terminal, Southeast Sulawesi, Indonesia. The Makassar Metro Terminal is a relocated terminal in 2003, this terminal was formerly located in Panaikang Terminal in 5 kilometers from the city center and it was located in suburb located in 15 kilometers. In its initial operation, this terminal is quite active providing services for intercity passengers, but along the time the passengers and operators tend to conduct the transit activity outside the terminal, either in Bus Pool, in informal terminal or directly door to door service. There are various policies taken to effective the terminal, but until now, there is no significant improvement.

In this research, this questionnaire is tested face validity, content validity. Assessment point of service quality uses Likert scale of 1-7 with " 1 = very unsatisfied, $4=$ neutral, into 7 $=$ very satisfied". The researcher received 350 questionnaires. The sample size for maximum likelihood (ML) estimation should be at least 15 times the number of observed variables $[15,16]$.

Tabel 2. Characteristic of respondent

\begin{tabular}{|l|c|l|}
\hline Atribut & Frequency & Percent \\
\hline Gender & 153 & \\
\hline Male, & 178 & $46,2 \%$ \\
Female & & $53,8 \%$ \\
\hline Age & 230 & \\
\hline $17-25$ years & 84 & $69,5 \%$ \\
26-40 years & 16 & $4,4 \%$ \\
$41-65$ years & 1 & $0,3 \%$ \\
65 or More & & \\
\hline Travel Purpose & 172 & $52 \%$ \\
\hline Go home & 83 & $25,1 \%$ \\
Private & 17 & $5,1 \%$ \\
Study & 35 & $10,6 \%$ \\
Bussiner & 24 & $7,3 \%$ \\
Others & & \\
\hline Occupation & 41 & $12,4 \%$ \\
\hline Wiraswasta & 30 & $9,1 \%$ \\
Government employee & 179 & $54,1 \%$ \\
Student & 46 & $13,9 \%$ \\
Private employee & 35 & $10,6 \%$ \\
Others & & \\
\hline Education & 105 & $31,7 \%$ \\
\hline SD-SMA & 108 & $32,6 \%$ \\
College Student & 29 & $8,8 \%$ \\
D1-D3 & 70 & $21,1 \%$ \\
S1 & 14 & $4,2 \%$ \\
S2 & 3 & $0,9 \%$ \\
S3 & 2 & $0,6 \%$ \\
Others & & \\
\hline
\end{tabular}

The first factors consisting 6 indicators namely environment quality, safety, lightning, facility, brokers and security that are categorized as Terminal Performance, this is in line with the factors prepared [13]. The second factors consist of four indicators namely support 
of public transportation, access from the Street, location, availability and clarity of information that are categorized as Connectivity. The third factors consist of four indicators namely porter, terminal staff service, Ease of carrying goods, Coordination transport Operators with administrator that are categorized as Easy Of Transfer. The fourth factors consist of three indicators namely Ease of purchasing tickets, availability of passenger bus/cars, and crew \& driver services that are categorized as Operator Performance. The fifth factors consist of two indicators namely waiting time and punctuality that are categorized as Reliability Service. Out of the formed factors, it can be seen that the passengers are less satisfied on the terminal performance with the average value is ranging from 3,5378-3,9698 and are quite satisfied on the operator performance with the average value is ranging from 5,0816-5,4562 meanwhile related to the connectivity, easy of transfer and reliability passenger's service, these tend to be neutral with each average value is ranging from 4,3172-4,4924, 3,6224-4,3837, 4,2205-4,2749. The reliability test uses alpha Cronbach's with the value above 0,7 as acceptable [17]. The alpha Cronbach values are ranging from $0,735-0,848$, so that it is considered acceptable the criteria.

\subsection{Structure equation model}

Tabel 3. Exploratory factor analysis

\begin{tabular}{|c|c|c|c|c|}
\hline No & $\begin{array}{c}\text { Factor (a, CVE) } \\
\text { Indicator }\end{array}$ & Mean & $\begin{array}{c}\text { Factor } \\
\text { Loading }\end{array}$ & Communalities \\
\hline & \multicolumn{4}{|c|}{ Terminal Performance $(a=0,805 \quad C V E=15,601 \%)$} \\
\hline P12 & $\begin{array}{l}\text { Environment Quality (Cleanliness } \\
\text {,Pollution, Temperature) }\end{array}$ & 3,5378 & 0,763 & 0,678 \\
\hline P11 & Safety & 3,9335 & 0,743 & 0,644 \\
\hline P10 & Lighting & 3,7734 & 0,707 & 0,635 \\
\hline P13 & Facilities (Toilet, Seat ,Shops) & 3,7372 & 0,699 & 0,586 \\
\hline P16 & Brokers of purchasing tickets & 3,9698 & 0,547 & 0,444 \\
\hline \multirow[t]{2}{*}{ P9 } & Security & 3,8610 & 0,505 & 0,552 \\
\hline & \multicolumn{4}{|c|}{ Connectivity $(a=0,735 \quad \mathrm{CVE}=13,798 \%)$} \\
\hline P3 & Support of Public Transportation & 4,3172 & 0,787 & 0,678 \\
\hline $\mathrm{P} 4$ & Access From the Street & 4,4924 & 0,729 & 0,658 \\
\hline $\mathrm{P} 2$ & Location Of terminal & 4,4743 & 0,632 & 0,544 \\
\hline \multirow[t]{2}{*}{ P1 } & $\begin{array}{l}\text { Avaibility \& Clarity Of Travel } \\
\text { Information }\end{array}$ & 4,4804 & 0,430 & 0,397 \\
\hline & \multicolumn{4}{|c|}{ Ease Of Transfer $(a=0,801 \mathrm{CVE}=12,800 \%)$} \\
\hline P8 & Porter & 3,6224 & 0,819 & 0,755 \\
\hline P7 & Terminal staff Service & 4,2024 & 0,700 & 0,681 \\
\hline P6 & Ease of carrying goods & 4,1692 & 0,593 & 0,610 \\
\hline \multirow[t]{2}{*}{ P5 } & $\begin{array}{l}\text { Coordination transport Operators with } \\
\text { administrator }\end{array}$ & 4,3837 & 0,557 & 0,646 \\
\hline & \multicolumn{4}{|c|}{ Operator Performance $(a=0,802 \mathrm{CVE}=12,286 \%)$} \\
\hline P15 & Ease of purchasing tickets & 5,4562 & 0,862 & 0,772 \\
\hline P14 & Availability of passenger bus / cars & 5,1299 & 0,794 & 0,744 \\
\hline P17 & Crew and driver service & 5,0816 & 0,651 & 0,614 \\
\hline & \multicolumn{4}{|c|}{ Realibility Service $(a=0,848$ CVE $=10,188 \%)$} \\
\hline P18 & Waiting Time & 4,2749 & 0,885 & 0,850 \\
\hline P19 & Punctuality & 4,2205 & 0,860 & 0,799 \\
\hline
\end{tabular}

Based on results of EFA, it is formed 5 factors consisting of Terminal performance, Connectivity, Easy of transfer, Operator performance, and Reliability Service. Then, it is conducted the model measurement forming covariance between factors. The first order 
model results in standardized factor loadings ranging from 0,51-0,88 with the acceptable value is above 0,50 [18], any values below this value is recommended to be eliminated (Hair et al., 2010, Janssens et al., 2008). The model fit indices for the first order (X2= 475,882, X2/df=3,328, GFI $=0,868 ;$ AGFI $=0,824 ; \mathrm{TLI}=0,845 \mathrm{NFI}=0,826 ; \mathrm{CFI}=0,870$; PNFI=0,728: PGFI $=0,653$ and RMSEA $=0,084 ; \mathrm{SRMR}=0,066$ ) does not acceptable. Therefore, it is necessary to conduct the modification indices to improve the model fit indices. After applying the modification indices covariance then it is examined on the Standardized Residual covariance values exceeding 2,58 and its results of P9, P10, P16,P7 are eliminated from the model.

The model fit indices for results of first order modification are $(\mathrm{X} 2=174,824$, $\mathrm{X} 2 / \mathrm{df}=2,241, \mathrm{GFI}=0,934 ; \mathrm{AGFI}=0,899 ; \mathrm{TLI}=0,932 ; \mathrm{NFI}=0,913 ; \mathrm{CFI}=0,949 ; \mathrm{PNFI}=0,679$ : $\mathrm{PGFI}=0,607$; and RMSEA $=0,061 ; \mathrm{SRMR}=0,047$ ). The AGFI value is lower then recommended however, it is still considered as the marginal model [19].

The calculated validity constructs are convergent validity and discriminant validity. Source of reference value to calculate Convergent validity is standardized loading factor, the lowest value to be recommended is 0,5 or more, the ideal value is 0,7 or more, the lowest AVE value is 0,5 or more [20,21]. Meanwhile to calculate the discriminant validity through AVE estimates for two factors also should be greater than the square of the correlation between the two factors to provide evidence of discriminant validity [22, 23]. Another method is used to test the discriminant validity if the average variance extracted (AVE) is greater than the maximum shared squared variance (MSV) or average shared squared variance (ASV). Discriminant validity was present when the correlation between two constructs was lower than the recommended value $r \leq 0.85$ [24]. Composite reliability should be 0.7 or higher to indicate adequate convergence or internal consistency CRE $>0.7$ [25]. Composite reliability and AVE are calculated based on the formulation [23].

Table 4. Results of discriminant validity test for service quality factor

\begin{tabular}{|l|c|l|l|l|l|l|l|c|}
\hline \multicolumn{1}{|c|}{ Factor } & AVE & CRE & MSV & ASV & $\mathbf{1}$ & $\mathbf{2}$ & $\mathbf{3}$ & $\mathbf{4}$ \\
\hline Terminal Performance & 0,55 & 0,78 & 0,35 & 0,2 & & & & \\
\hline Connectivity & 0,45 & 0,76 & 0,72 & 0,37 & 0,52 & & & \\
\hline Easy Of Transfer & 0,51 & 0,80 & 0,72 & 0,38 & 0,59 & 0,85 & & \\
\hline Operator Performance & 0,70 & 0,82 & 0,27 & 0,19 & 0,24 & 0,53 & 0,52 & \\
\hline Realibility Service & 0,73 & 0,84 & 0,19 & 0,15 & 0,34 & 0,44 & 0,40 & 0,38 \\
\hline
\end{tabular}

Based on results of construct validity as seen in table 4 , it is obtained that there is a factor having low AVE value, namely connectivity by 0,45 however if referring that the AVE value is taken from the factor loading value, based on this that the factor loading that can be in the terminal is greater by 0,5 then the factors are still inputted in the interpretation. Meanwhile for the Discriminant validity, it can be seen that there are two factors with smaller AVE values than MSV namely Connectivity and Easy of transfer, if using the argument [24] stating that the highest factor correlation value is 0,85 then it is considered to acceptable the criteria. The lowest Composite reliability value is 0,78 and the highest one is 0,94 . The values are greater than 0,7 then these factors acceptable the composite reliability. As conclusion, modification of model fit indices acceptable the criteria, also by the convergent validity and discriminant validity considered acceptable by recommended values. This modification model is then used for the second order model as seen in figure 1. 


\section{Study method}

This research is to test the factors forming from 19 indicators of service quality of intercity bus terminal. Its initial indicators are tested using exploratory factor analysis, the results obtain 19 indicators that are classified into 5 categories namely terminal performance, connectivity, easy of transfer, operator terminal, reliability service. Results of EFA are then analyzed using SEM to confirm the forming factors. There are some researches almost similar to the forming factors in this research, namely [13] studying on intercity bus service, there are two similar factors, namely terminal performance and operator performance. The factors from a research [9] are accessibility that is similar to connectivity and timeliness that is similar to reliability service. The factor formed from a research [5] is transfer condition that is similar to easy of transfer. This word difference is because the transfer condition refers more to condition while the easy of transfer refers to activity purpose.

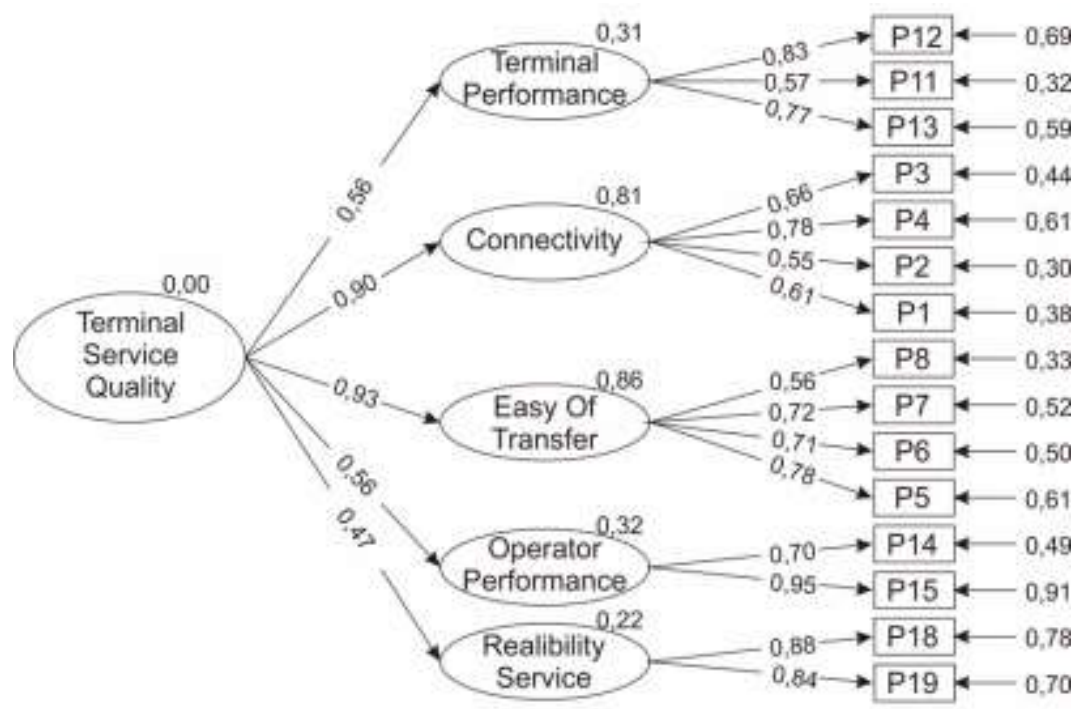

$(\mathrm{X} 2=189,367, \mathrm{X} 2 / \mathrm{df}=2,309, \mathrm{GFI}=0,929 ; \mathrm{AGFI}=0,896 ; \mathrm{TLI}=0,928 ; \mathrm{NFI}=0,906 ; \mathrm{CFI}=0,944 ;$ PNFI $=0,708$ : PGFI $=0,635 ;$ dan RMSEA $=0,063 ;$ SRMR $=0,0521$ )

Fig. 1. Model result of second-ordered confirmatory factor analysis

Based on results of CFA, out of 19 indicators, there are 4 indicators to be eliminated to obtain model fit indices. The indicators are because the standardized covariance error value is more than 2,58. Based on the factor loading value in CFA in this research, it is stated that there will be an improvement on terminal service by prioritizing respectively on easy of transfer, connectivity, operator performance, terminal performance and reliability service. From the ease of transfer, the high factor loading value is P4 related to terminal Access from the Street, this is because currently the terminal is located 500 meters from arterial roads. The connectivity indicator having high factor loading is P5 Coordination transport Operators with administrator. The operator performance indicator having high factor loading is P15 namely ease of purchasing tickets, although average passengers are quite satisfied with this indicator. The terminal performance indicator having high factor loading is P12 namely environmental quality, average passengers are quite satisfied with this indicator, this is in line with the condition that there are some points in the terminal providing less attention at cleanliness, although in passenger circulation, it can be seen an effort to improve the environmental cleanliness. At last, there ability service indicator 
having high factor loading is P18 namely waiting time, the passengers while waiting for the departure can spending their time with available facilities, so that the passengers are not bored at waiting [5].

\section{Conclusions}

Terminal development in Indonesia based on regulations directs the terminal location on suburb and enters arterial road, so that there is similar problem faced in the terminal namely the passengers are reluctant to transit in the terminal because of poor location and lack of public transport services in the city. Therefore, it is necessary to study in further the policy of relocating the terminal in the suburbs, the location selection does not only consider in the suburban area but also on its accessibility. If the terminal has been relocated then there are two policies that can be taken to improve the terminal services performance, namely:

1. Ease of transfers: this service priority is to ensure that passengers who will transit can conduct any activity smoothly and without any constraints or interference, this can be done first by creating effective coordination between operators and administrator so that it can work together in a synergistic manner. Second, it is through proactive and friendly attitude from terminal management staff assisting passenger transit activities. Third is to minimize passengers' difficulty in carrying their goods such as provide of trolley and porter.

2. Connectivity: this service is done firstly by increasing connectivity of selected location which is easily accessed one from supporting roads or locations. Second, there is provided information about passenger travel need related to arrival, departure schedules, bus availability and others. Third, there is adequate provision of alternative transportation means in the city so that it can support terminal services.

For further researches, it is necessary to conduct in some relocated terminal so that it can draw proper conclusion concerning any factors giving impacts on quality of terminal services as well as determine on a variety of problems faced as a result of relocation.

\section{References}

1. Dimitriou, H.T. A Developmental Approach to Urban Transport Planning: An Indonesian Illustration, Oxford University Press, Kualalurnpur, Malaysia. (1993),

2. Ceder, Avishai. 2007. Public Transit Planning and Operation: Theory, Modeling and Practice. Transport. Elsevier: Butterworth- Heinemann.

3. Augustin,K.,Gerike,R.,Sanchez,M.J.M.,Ayala,C.Analysis of intercity bus markets on long distances in an established and a young market: The example of the U.S. and Germany. Res. Transp. Econ.48,245-254, Elsevier ,(2014).

4. Yatskiv, Irina, Vaira Gromule, Nadezda Kolmakova, and Irina Pticina.. "Development Of The Indicator Of Service Quality." Proceedings of the 9th International Conference "Reliability and Statistics in Transportation and Communication" (RelStat'09), 21-24 October 2009, Riga, Latvia, P. 124-133. ISBN 978-9984-818-21-4 Transport and Telecommunication Institute, Lomonosova 1, LV, no. October: 124-33. (2009).

5. Hernandez, S., Monzon, A., Key factors for defining an efficient urban transport interchange: users' perceptions. Accepted in J.Cities. (2015).

6. Abreu e Silva, J., Bazrafshan, H., User satisfaction of intermodal transfer facilities in Lisbon, Portugal: analysis with structural equations modeling. Transp. Res. Rec. J. Transp. Res. Board 2350, 102-110.( 2013) 
7. Hine, J., Scott, J.,. Seamless, accessible travel: users' views of the public transport journey and interchange. Transp. Policy 7 (3), 217-226. (2000).

8. Dell'Asin, Giulia. “Key Quality Factors And Travellers Profiles At Interurban Interchanges.” Thesis Doctoral, 53722. (2014).

9. De Oña, J., de Oña, R., Eboli, L., Forciniti, C., Mazzulla, G., Transit passengers' behavioural intentions: the influence of service quality and customer satisfaction. Transp. A Transp. Sci. 12 (5), 385-412. (2016).

10. Eboli, Laura, Yanbing Fu, and Gabriella Mazzulla.. "Multilevel Comprehensive Evaluation of the Railway Service Quality." Procedia Engineering 137. Elsevier B.V.: 21-30. (2016).

11. Nathanail, E., Measuring the quality of service for messengers on the Hellenic railways. Transp. Res. Part A 42, 48-66. (2008).

12.Iseki, H., \& Taylor, B.D. Style versus service? An analysis of user perceptions of transit stops and stations. Journal of Public Transportation, 13(3), 23-48. (2010).

13.Wen, C.-H., Lan, L., Cheng, H.-L., Structural equation modeling to determine passenger loyalty toward intercity bus services. Transp. Res. Rec.: J. Transp. Res. Board 1927, 249-255. (2005).

14.Bordagaray, M., dell'Olio, L., Ibeas, A., Cecín, P. Modelling user perception of bus transit quality considering user and service heterogeneity. Transp. A: Transp. Sci., 117. (2013).

15.Stevens, J., Applied Multivariate Statistics for the Social Sciences. Lawrence Erlbaum Associates, NJ. (1966).

16.Golob, T.F., Structural equation modeling for travel behavior research. Transp. Res. Part B: Methodol. 37 (1), 1-25. (2003).

17. Wittwer, R. Cluster-analytical-creation of a typology of young adults' travel behavior in Germany. España: Presented at the XI Congreso de Ingeniería del Transporte, CIT 2014, Santander. (2014).

18.Bagozzi, R. P., \& Yi, Y. On the evaluation of structural equation models. Journal of the Academy of Marketing Science, 16(1), 74-94. (1988).

19.Hair, J. F. J., Black, W. C., Babin, B. J., Anderson, R. E., \& Tatham, R. L. Multivariate data analysis (6th ed.). Upper Saddle River, NJ: Pearson Prentice Hall. (2006).

20.Anderson, J. C., \& Gerbing, D. W, Structural equation modeling in practice: A review and recommended two-step approach. Psychological Bulletin, 103(3), 411- 423. . (1988a).

21.John, G., \& Reve, T. The reliability and validity of key informant data from Dyadic relationships in marketing channels. Journal of Marketing Research, 19(4), 517- 524. (1982).

22.Bagozzi, R. P., \& Phillips, L. W. Representing and testing organizational theories: A holistic construal. Administrative Science Quarterly, 27(3), 459-489. (1982).

23. Fornell, C., \& Larcker, D. F. Evaluating structural equation models with unobservable variables and measurement error. Journal of Marketing Research, 18(1), 39-50. (1981).

24.Kline, R. B. Principles and practice of structural equation modeling (2nd ed.). New York, NY: Guilford Press. (2005).

25.Hair, J. F. J., Black, W. C., Babin, B. J., \& Anderson, R. E. Multivariate data analysis: A global perspective (7th ed.). Upper Saddle River, NJ: Pearson Education. (2010). 
26.Janssens, W., Wijnen, K., Pelsmacker, P. D., \& Kenhove, P. V. Marketing research with SPSS. Harlow, England; New York: Prentice Hall/Financial Times. (2008).

27.Kaiser, H. F., \& Rice, J. Educational and psychological measurement. Little Jiffy, Mark IV, 34, 11. (1974).

28.Kim, J. A multidimensional and hierarchical model of integrated service quality for the Internet golf stores. Retrieved from http://dl.acm.org.ezproxy.lincoln.ac.nz/citation.cfm?id=979102. (2003).

29.Land, L., and C. Foreman. Neighborhood Intermodal Transfer Facilities. Report no. NCTR-392-16. Research and Special Programs Administration, U.S. Department of Transportation, Florida Department of Transportation and University of South Florida, Center for Urban Transportation Research, and National Center for Transport Research, Tampa, Fla., (2001).

30.Tabachnick, B. G., \& Fidell, L. S. Using multivariate statistics (5th ed.). Boston: Pearson/Allyn \& Bacon. (2007). 